\title{
PEMBELAJARAN BAHASA INGGRIS UNTUK ANAK USIA DINI: 15 PRINSIP PENDEKATAN DAN METODE PEMBELAJARAN OLEH PROFESSOR JACK C. RICHARD
}

\author{
Oleh \\ I Dewa Gede Rat Dwiyana Putra \\ Institut Hindu Dharma Negeri Denpasar \\ ratdwiyanaputra@gmail.com
}

\begin{abstract}
English is not a compulsory subject in early childhood education (ECD) curriculum in Indonesia. However, practically, many ECD schools implement English language learning which adds value to the existence of the ECD School itself, in addition to the demand of parents. Therefore, many problems arise in the ELT practice in ECD schools, one of which is the problem of the appropriateness of approaches and methods of ELT applied to the young learner. This article aims to promote the English learning approaches in teaching English for young learner (TEYL) that have been presented by Professor Jack C. Richard in his official web page, complemented by methods that can be implemented by ECD school Teachers. Several related studies on the effectiveness of the method are also presented to provide empirical evidence from various contexts. Finally, conclusions and suggestions about TEYL approaches and methods are addressed to readers, especially for ECD practitioners and researchers interested in TEYL.
\end{abstract}

Keywords: Approach, Method, English Languge Teaching, Early Childhood.

\begin{abstract}
Abstrak
Bahasa Inggris merupakan mata pelajaran yang tidak diwajibkan dalam kurikulum PAUD di Indonesia. Namun, dalam praktiknya banyak Sekolah PAUD melaksanakan pembelajaran Bahasa Inggris yang memberikan nilai tambah untuk keberadaan Sekolah PAUD itu sendiri disamping karena adanya permintaan orang tua siswa. Oleh karena itu, banyak permasalahan yang muncul dalam praktiknya di sekolah-sekolah PAUD, salah satunya adalah permasalahan tentang kesesuaian pendekatan dan metode pembelajaran Bahasa Inggris yang diterapkan untuk AUD. Artikel ini bertujuan untuk memaparkan kembali pendekatan-pendekatan pembelajaran Bahasa Inggris untuk AUD yang telah disampaikan oleh Professor Jack C. Richard pada halaman web-nya, dilengkapi dengan metode-metode yang dapat diimplementasikan oleh Guru PAUD. Beberapa penelitian yang terkait tentang effektivitas dari metode tersebut juga dipaparkan untuk memberikan bukti empiris dari berbagai konteks.

Pada bagian akhir, kesimpulan dan saran mengenai mengenai metode ini disampaikan kepada pembaca, terutama dari kalangan praktisi PAUD dan peneliti yang tertarik pada bidang pendidikan Bahasa Inggris untuk Anak Usia Dini.
\end{abstract}

Kata Kunci: Pendekatan, Metode, Pembelajaran Bahasa Inggris, Anak Usia Dini.

\section{PENDAHULUAN}

Berbagai gejala kemajuan jaman telah menempatkan Bahasa Inggris sebagai bahasa yang sangat diminati oleh masyarakat dunia. Berbagai teknologi muktahir seperti smartphone atau gadget 
lainnya sebagian besar menggunakan Bahasa Inggris sebagai bahasa defaultnya, karena produsen-produsen elektronik telah menyadari bahwa Bahasa Inggris dapat diterima di berbagai belahan dunia. Disamping itu, berbagai level pendidikan di negara-negara yang masyarakatnya bukan penutur Bahasa Inggris telah memasukkan Bahasa Inggris dalam kurikulum pembelajarannya.

Indonesia sendiri adalah negara yang menempatkan Bahasa Inggris sebagai bahasa Asing karena Bahasa Inggris bukanlah bahasa yang digunakan dalam komunikasi sehari-hari di berbagai institusi formal maupun informal. oleh karena itu, pembelajaran Bahasa Inggris bersifat pembelajaran bahasa Inggris sebagai bahasa Asing (Teaching English as a Foreign Laguange). Implikasinya terlihat dalam berbagai aspek, salah satunya adalah dalam penyusunan struktur kurikulum pendidikan pada berbagai level pendidikan dimana Bahasa Inggris mendapatkan porsi yang tidak terlalu banyak dibandngkan dengan Bahasa Indonesia atau Matematika dan mata pelajaran penentu lainnya.

Peraturan Menteri Pendidikan dan Kebudayaan Republik Indonesia Nomor 137 tahun 2014 tentang Standar Nasional Pendidikan Anak Usia Dini telah menentukan substansi pembelajaran bahasa untuk Anak Usia Dini. Dalam Lampiran 1 Permendikbud no 137 tahun 2014, dalam lingkup perkembangan memahami bahasa pada usia 4-5 tahun, tingkat pencapaian yang diharapkan adalah; "menyimak perkataan orang lain (bahasa ibu atau bahasa lainnya)" dalam point tersebut, secara tidak langsung pemerintah memberikan kesempatan kepada penyelenggara pendidikan AUD untuk mengatur bahasa-bahasa yang diajarkan kepada AUD tidak terbatas pada bahasa Ibu saja. Dalam praktiknya, banyak penyelenggara pendidikan AUD di daerah yang memiliki bahasa lokal yang merupakan bahasa Ibu, juga mengajaran Bahasa Indonesia sebagai bahasa kedua dan bahasa pengantar pembelajaran bahkan sebagian besar mengajarkan bahasa asing, diantaranya Bahasa Inggris dan Bahasa Jepang atau Bahasa Asing lainnya.

Bali sebagai tujuan pariwisata dan daerah yang ramah perkembangan jaman memberikan alasan yang kuat bagi masyarakatnya untuk memberikan pembelajaran Bahasa Inggris kepada anak-anaknya sejak dini. Oleh karena itu, orang tua AUD cenderung memilih sekolah PAUD yang memiliki program bahasa Inggris untuk menyekolahkan anaknya. Untuk menyesuaikan dengan hal tersebut, PAUD-PAUD baik negeri maupun swasta pun berlomba-lomba untuk memprogramkan Bahasa Inggris sebagai nilai tambah untuk menarik minat masyarakat.

Namun pada kenyataannya banyak pertanyaan yang muncul dari pelaksanaan pembelajaran Bahasa Inggris untuk Anak Usia Dini, salah satunya adalah mengenai pendekatan dan metode yang digunakan dalam melaksanakan pembelajaran Bahasa Inggris di sekolah PAUD. Artikel ini memaparkan beberapa pendekatan 
dan metode effektif yang dapat diimplementasikan dalam pembelajaran Bahasa Inggris pada AUD.

\section{PEMBAHASAN}

Pada bagian ini penulis memaparkan kembali 15 prinsip pembelajaran AUD yang disampaikan oleh Professor Jack C. Richard di halaman web resminya (www. professorjackrichards.com), ditambahkan dengan cara mengimplementasikanya di kelas serta penelitian-penelitian yang relevan. Pendekatan-pendekatan tersebut antara lain;

\section{A. Laksanakan pembelajaran yang penuh dengan aktivitas siswa dan gerakan fisik}

Dalam melaksanakan pembelajaran Bahasa Inggris, guru-guru PAUD disarankan untuk selalu menghubungkan pembelajaran bahasa dengan kegiatankegiatan yang memerlukan gerakan fisik siswa. Siswa dapat membuat kerajinan tangan, menggambar, mencocokkan gambar, bermain peran atau permainan lainnya dan kegiatan-kegiatan lain yang memberikan kesempatan siswa untuk beraktivitas dengan mengkoordinasikan fungsi pengelihatan, pendengaran dan gerakan badan. Metode pembelajaran ini disebut dengan Total Physical Response $(T P R)$. Metode ini menekankan pada aktivitas siswa yang dilaksanakan berdasarkan instruksi yang diberikan oleh Guru dalam bahasa Inggris, seperti "Sit down; Open your mouth; Rise your hand; Kick the ball" dan lain-lain. Kegiatan- kegiatan lain seperti “dengarkan lalu pilih gambar; dengarkan lalu gambarlah; dengarkan lalu pasangkanlah, dan lain-lain" dapat dilaksanakan dengan memberikan instruksi berbahasa Inggris serta dikombinasikan dengan kegiatan bernanyi yang disertai gerakan-gerakan yang menyenangkan.

Rokhayani (2017) melaksnakan sebuah penelitian qualitatif untuk mendeskripsikan proses belajar dan mengajar yang dilaksanakan di sebuah TK di Kudus, Jawa Tengah. Pada penelitian tersebut, peneliti berkolaborasi bersama gurudiTK tersebutuntukmengaplikasikan metode Total Physical Response (TPR) dalam pembelajaran Bahasa Inggris untuk AUD sambil mengobservasi kegiatan yang berlangsung. Dalam proses pembelajaran, TPR sangat tepat jika dilaksanakan dengan menyanyikan lagu "Head, Shoulder, Knees and Toes" karena dengan lagu ini, prinsip-prinsip TPR dapat terpenuhi. Dalam temuannya, Rokhayani (2017) memaparkan bahwa metode ini dapat menarik perhatian siswa untuk terlibat dan berpartisipasi aktif dalam pembelajaran. Dengan adanya partisipasi siswa tersebut, guru dengan mudah memperkenalkan kosa kata baru melalui lagu dan ketika siswa melakukannya dengan gerakan, siswa dapat mengingatnya dengan mudah. Penelitian yang dilaksanakan oleh Rokhayani (2017) menyimpulkan bahwa TPR merupakan metode yang effektif untuk diaplikasikan untuk pembelajaran Bahasa Inggris di PAUD. 


\section{B. Laksanakan pembelajaran dengan aktivitas-aktivitas yang saling berhubungan}

Dalam mengikuti pembelajaran, anak-anak cenderung cepat merasa bosan karena mereka hanya dapat memperhatikan pembelajaran dalam waktu yang relatif singkat dibandingkan dengan orang dewasa. Oleh karena itu, guru diharapkan dapat mempersiapkan beberapa aktivitas kecil yang saling berhubungan dalam suatu pembelajaran. Kemudian, guru dapat memilih salah satu kegiatan untuk memulai pembelajaran, kemudian berganti ke kegiatan baru sesuai dengan tahap-tahap pembelajaran atau berganti kegiatan untuk pemantapan pemahaman siswa. Pergantian kegiatan ini diharapkan terjadi dengan mulus dan cepat, oleh karena itu, kegiatankegiatan yang dipersiapkan harus saling berhubungan satu sama lain. Menurut Prof. Jack C. Richard, aktivitas yang terbaik dan paling effektif adalah aktivitas yang dilaksanakan antara 5-10 menit.

Ada beberapa kegiatan yang bisa dikombinasikan di dalam kelas untuk menarik partisipasi sisa sehingga siswa tidak mudah bosan. Guru bisa memulai pelajaran membagi siswa menjadi 2 kelompok. Pembagian kelompok dilakukan dengan cara bermain, misalnya; "ular naga panjang". Anak-anak diajak untuk bernyanyi dan mengikuti permainan tersebut sampai terbentuk dua kelompok. Dari kegiatan pembagian kelompok ini, guru dengan cepat mengarahkan anak untuk bersiap melakukan permainan lainnya dimana pesertanya terdiri dari kelompok yang telah terbentuk. Permainannya bisa beraneka ragam, diantaranya adalah tebak gambar, tebak nama benda, tebak warna, dan lain sebagainya. Selanjutnya, guru bisa mengubah kegiatan lain yang masih berhubungan dengan permainan sebelumnya. Misalnya sebelumnya guru melakukan permainan tebak warna, kegiatan selanjutnya adalah permainan menemukan warna yang telah ditebak di sekitar kelas. Inti dari perubahan dari satu kegiatan ke kegiatan yang lain adalah keterkaitan dari kegiatan tersebut, jadi siswa tidak susah untuk melaksanakan kegiatan selanjutnya. Disamping itu, guru tetap dapat mengatur fokus kegiatan pada satu hal pokok yang menjadi tujan pembelajaran.

\section{Laksanakan pembelajaran dengan tugas-tugas yang bermakna}

Tugas ini lebih ke suatu kegiatan yang bermakna dan dapat dilaksanakan oleh siswa berdasarkan instruksi yang jelas dari guru. Pada pembelajaran dengan pendekatan ini, siswa diharapkan mampu untuk mempergunakan atau menunjukkan kemampuan bahasa Inggrisnya untuk menyelesaikan tugastugas yang diberikan oleh guru. Tugastugas tersebut dapat dilaksanakan secara berpasangan, berkelompok ataupun dilakukan oleh seluruh kelas secara bersamaan. Kembali pada prinsip yang pertama, seluruh kegiatan yang dilaksanakan harus memanfaatkan panca indera serta gerakan tubuh. Namun, pada prinsip ini, Prof. Jack C. Richard menekankan pada pemilihan suatu tugas 
utama yang memerlukan beberapa aspek yaitu;

a. Kegiatan yang terintegrasi mulai dari topik, aktivitas serta hasil kegiatan.

b. Tujuannya jelas dan mermanfaat untuk anak

c. Memiliki target pembelajaran bahasa yang jelas, dan

d. Menarik partisipasi aktif anak

\section{Laksanakan pembelajaran} dengan menyediakan scaffolding

Menyediakan Scaffolding dapat berarti berarti memberikan kesempatan pada anak untuk belajar secara kolaboratif dengan orang disekitarnya seperti; teman yang lebih mampu, guru, maupun orang tua dalam mengerjakan suatu aktivitas. Fungsi adanya Scaffolding ini adalah untuk menyediakan bantuan yang bermakna dalam bentuk instruksi, motivasi, pemecahan masalah, dll kepada anak pada diawal kegiatan sebelum dia dapat melaksanakan kegiatannya dengan mandiri. Scaffolding sebenarnya diambil dari kata struktur yang dibagun disekitar gedung untuk mempermudah pembangunan gedung (pemasangan kaca, pengecatan, dll) dan akan dilepaskan begitu gedungnya selesai dibagun. Misalnya dalam melaksanakan kegiatan mencocokkan warna dan labelnya, siswa dengan kemampuan tinggi dapat menyediakan bantuan untuk siswa yang mengalami kesulitan dalam mengenali nama warna tersebut dalam Bahasa Inggris.

Sebuahpenelitianyangdilaksanakan oleh Pentimoni (2011) menunjukkan bahwa, scaffolding mampu meningkatkan kemampuan siswa dalam perbendaharaan kata yang baru. Penelitian tersebut juga menemukan bahwa tehnik scaffolding dengan memberikan bantuan secukupnya kepada siswa, dapat mempengaruhi kemampuan perbendaharaan kata siswa.

\section{E. Libatkan siswa dalam menentukan sumber belajar}

Siswa akan sangat senang jika diberi kesempatan untuk memilih sendiri tokoh pahlawan dalam kartun untuk dibawa ke sekolah, diwarnai kemudian dipajang di kelas. Guru dapat memanfaatkan hal ini untuk mengajarkan warna, bagian tubuh, bentuk dan lain-lain dalam bahasa Inggris. Professor Jack C. Richard bahkan menyebutkan bahwa beliau memiliki sebuah kelas untuk anak-anak di Quebec, Kanada dimana kelas tersebut memakai Coursebook (buku kerja) buatan siswanya sendiri dan pelajaran dikembangkan dari buku kerja tersebut.

\section{F. Laksanakan pembelajaran dengan tema tertentu}

Untuk anak usia dini, Guru disarankan untuk memperkenalkan tema-tema yang dekat dengan siswa seperti hewan, tumbuhan, makanan, teman, dan keluarga. Setelah itu baru dapat mengambil tema-tema lain seperti pekerjaan, alat trasportasi, tempat umum dan lain-lain. Dengan melaksanakan pembelajaran berdasarkan tema tertentu, guru akan lebih mudah dalam memilih kegiatan pembelajaran yang nyata dan bermanfaat untuk kehidupan sehari-hari. 
Dengan pemilihan tema pembelajaran yang dekat dengan kehidupan siswa, pembelajaran tidak mungkin terlepas dari budaya lokal. Sebuah artikel yang ditulis oleh Stojkovic \& Zivkovic (2013) disebutkan bahwa dalam mengembangkan kesadaran budaya anak didik tentang bahasa asing yang seang dipelajarinya, budaya asli anak didik tersebut juga harus dihadirkan dalam pembelajaran untuk memperkenalkan anak dengan multikulturalisme.

\section{G. Pilihlah topik dan materi pembelajaran yang mudah dikenali siswa}

Pemilihan topic dan materi pembelajaran dapat bervariasi, salah satunya sesuai dengan kedekatan atau latar belakang pengetahuan siswa. Oleh karena itu, konten pembelajaran berupa nama-nama tumbuhan, hewan, pekerjaan, tempat umum, cerita rakyat, peristiwa penting dan bersejarah bisa diambilkan dari lingkungan sektar yang dekat dengan siswa. Hal ini bertujuan untuk mempermudah siswa dalam mengenali topik-topik tersebut sehingga mempermudah siswa untuk mengungkapkannya dalam bahasa yang biasa mereka pergunakan ataupun bahasa baru yang sedang diajarkan dan dipelajari seperti Bahasa Inggris.

Ekplorasi cerita rakyat merupakan salah satu cara menemukan materi pembelajaran yang sangat familiar dengan siswa. Cerita rakyat Indonesia seperti "Bawang Merah \& bawang Putih", "Timun Mas", "Lutung Kasarung", "Manik Angkeran", dan lain-lain dapat kita ambil untuk dibahas bersama anakanak, bukan hanya dari segi ceritanya, tapi juga hal-hal lain yang ada dicerita tersebut, seperti hewan, tumbuhan, pakaian, hutan, pantai, gunung dan lain-lain. Kedekatan dan familiaritas akan terjadi jika cerita yang kita pilih merupakan cerita rakyat di daerah yang merupakan cerita yang sangat dikenali oleh siswa, bahkan, jika siswa diperkenalkan dengan nama daerahnya, siswa akan dngan mudah mengenali daerah tersebut. Begitu juga nama-nama hewan, tumbuhan dan lain sebagainya. Jadi, guru tidak perl bingung dalam memilih materi pembelajaran. Pilihlah materi yang sangat dekat dengan siswa.

\section{H. Pilihlah kegiatan pembelajaran yang dapat dikerjakan berkelompok}

Anak usia dini sangat senang berinteraksi dan bersosialisai baik dengan teman sekelas dan guru di kelasnya. Oleh karena itu, kegiatan yang memberikan siswa kesempatan untuk bekerja dalam kelompok merupakan kegiatan yang disarankan untuk dilakukan dalam pembelajaran untuk anak usia dini, terutama pembelajaran Bahasa Inggris. Dengan memberikan kegiatan baik berpasangan atau berkelompok, siswa dapat terlibat secara aktif dalam pembelajaran dan belajar berinteraksi dalam waktu yang relatif bersamaan.

Berbagai penelitian telah membuktikan effektivitas kolaborasi siswa terhadap keberhasilan belajarnya di kelas. Salah satunyaadalah penelitian yang dilakukan oleh Fawcet \& Garton (2005) 
yang terfokus pada effek pembelajaran kolaboratif terhadap kemampuan siswa dalam menyelesaikan masalah. Penelitian tersebut dilaksanakan pada 100 anak yang berumur antara 6-7 tahun. Anakanak tersebut diminta untuk melakukan penyusunan kartu-kartu yang sebelumnya telah diacak baik secara individu maupun berpasangan (jenis kelamin sama). Anak dengan kemampuan kurang dipasangkan dengan anak yang memiliki kemampuan lebih, kemudian diminta untuk menyusun kartu baik dalam kondisi saling berbicara ataupun tidak saling berbicara.

Dalam penelitian tersebut, Fawcet \& Garton (2005) menemukan bahwa, anak yang berkerjasama dengan baik dengan pasangannya dapat menyusun kartu dengan benar, lebih banyak dari anak yang bekerja secara individu. Disamping itu, murid yang memiliki kemampuan rendah dapat menunjukkan peningkatan dalam kemampuan penyelesaian masalah jika anak tersebut mau bekerjasama dengan pasangannya dengan baik. Seluruh temuan tersebut menunjukkan bahwa pembelajaran secara kolaboratif sangat bermanfaat bagi anak-anak untuk meningkatkan kemampuan mereka dalam menyelesaikan masalah.

\section{Ciptakanlah suasana belajar yang saling mendukung antar siswa di kelas}

Guru disarankan untuk dapat menciptakan suatu komunitas pembelajar (community of learner) didalam kelas dimana seluruh siswa dapat saling mendukung dan membantu satu sama lain dalam belajar untuk mencapai tujuan yang sama. Professor Jack C. Richard menyebutkan bahwa suasana kelas yang dibangun dengan semangat ini lebih produktif daripada kelas konvensional yang mengenyampingkan prinsip komunitas pembelajar. Disamping itu, siswa juga menjadi lebih bersemangat, memberi respon positif dan lebih percaya diri.

\section{J. Pilihlah aktivitas yang menyenangkan yang dapat dikerjakan tanpa membuat siswa merasa frustasi}

Anak usia dini sangat senang terlibat dalam kegiatan yang memiliki tantangan, tetapi dapat dijangkau oleh kemampuan siswa. Oleh karena itu, peran guru disini sangat penting dalam pemilihan kegiatan yang tepat untuk merangsang minat siswa dalam belajar Bahasa Inggris. Sebaliknya, pemilihan kegiatan yang terlalu sulit dapat menyebabkan siswa menjadi frustasi dan menurunkan semangat mereka untuk belajar.

\section{K. Sediakan sarana dan pra-sarana pendukung pembelajaran bahasa Inggris \\ Professor Jack C. Richard} menyebutkan bahwa guru memiliki tugas penting dalam memberikan dukungan berupa contoh cara pengucapan, demonstratsi kegiatan dan hal-hal pendukung lainnya untuk membantu siswa untuk terlibat dalam kegiatan pembelajaran. Namun, disamping itu, sarana pembelajaran seperti poster, flashcard, buku cerita bergambar, dan berbagai media lainnya yang berbahasa 
Inggris adalah bentuk-bentuk language suport yang berguna sebagai sumber belajar. Disini dibutuhkan kreativitas guru untuk memanfaatkan hal-hal tersebut sesuai dengan prinsip-prinsip yang telah dijelaskan sebelumnya.

\section{Sampaikan tujuan pembelajaran dan berikan umpan balik (feedback) dengan jelas}

Menyampaikan tujuan pembelajaran dengan jelas di awal pembelajaran memberika kesempatan pada siswa untuk mempersiapkan diri dalam mencapai tujuan tersebut, dan anak juga akan dapat belajar untuk membedakan dengan jelas sampai tahap mana mereka dinyatakan berhasil dan tidak berhasil. Anak usia dini sangat senang juka mereka menyelesaikan tugas dengan baik dan mendapatkan pencapaian tertentu. Disamping itu, ketika mereka sudah mampu mencapai tujuan yang telah kita tentukan, berikan penghargaan dalam bentuk bintang, stiker, poin, tanda senyum, dll. Sebaliknya jika ada siswa yang tidak menunjukkan pencapaian seperti temannya yang lain, berikan umpan balik mengenai letak kekurangannya dengan jelas.

Penelitian tentang umpan balik adalah satu topik yang sangat diminati baik di bidang psikologi dan pendidikan. Sebuah review hasil penelitian tentang feedback dilakukan oleh Henderlong \& Lepper (2002) yang menyatakan bahwa pujian itu berpengaruh pada motivasi internal siswa, kemandirian siswa, kepercayaan diri siswa, yang kemdian akan meningkatkan kemampuan hasil belajar siswa. Oleh karena itu, seorang guru PAUD harus mampu menentukan posisi dimana siswanya pantas untuk dipuji atas keberhasilannya dalam mengikuti pelajaran. Guru juga harus tegas dan jelas dalam memberikan aturanaturan pembelajaran dan memberikan sanksi yang sesuai (berdasarkan perjanjian di awal) kepada anak yang tidak disiplin. Hal ini akan mengajarkan siswa mengenai target yang harus dicapai dan pengetahuan tentang konsekwensi dari pencapaian target tersebut.

\section{Gunakanlah bahasa Inggris dalam memberi instruksi majemen kelas}

Mulailah dengan memberikan instruksi bahasa Inggris pada setiap kegiatan kelas, seperti berbaris (line up please!), membentuk kelompok (please make a group of ....), warnai bunga ini (Color the flower) dan lain-lain. Dengan menggunakan Bahasa Inggris dalam instruksi kelas, anak didik dapat menerima input bahasa lebih banyak sehingga mereka terbiasa mendengarkan dan merespon pada Bahasa Inggris. Setelah mereka berhasil merespon kegiatan tersebut, mereka diarahkan untuk mempergunakannya sendiri ketika berinteraksi dengan temannya. Contoh yang sangat sederhana yaitu kegitan berbaris. Pada saat berbaris, pemimpin barisan (murid) diarahkan untuk menggunakan bahasa Inggris untuk memimpin temannya. Hal ini dapat dilakukan secara bergantian setiap hari. Guru juga dapat mengkombinasikan prinsip penggunaan instruksi bahasa 
Inggris ini dengan pemberian pujian. Jadi guru dapat memberikan pujian bagi anak yang dapat memimpin barisan, memmimpin doa dengan baik setiap harinya.

N. Gunakan (mother tongue/L1) bahasa ibu atau bahasa yang biasa dipakai oleh anak-anak jika diperlukan

Sebuah pembelajaran Bahasa Inggris untuk AUD yang terpusat pada aktivitas memiliki kekuatan pada penyampaian instruksi yang jelas. Walaupun prinsip ini berbanding terbalik dengan prinsip sebelumnya, dimana siswa akan semakin banyak belajar jika seluruh instruksi menggunakan bahasa Inggris, disini Guru disarankan untuk mempergunakan bahasa Ibu siswa menjelaskan makna kata ataupun menjelaskan kegiatan agar lebih jelas.

Pengunaan bahasa Ibu atau bahasa pertama dalam pembelajaran bahasa Inggris sebagai bahasa asing masih diperdebatkan sisi effektifitasnya. Beberapa ahli berpendapat bahwa jika bahasa pertama semakin banyak digunakan dalam kelas bahasa asing, murid akan mengalami penurunan motivasi untuk mulai mempergunakan bahasa yang mereka sedang pelajari. Dan sebaliknya, para ahli yang lain beranggapan jika bahasa pertama dapat memberikan effek positive, karena bahasa pertama dapat dipergunakan untuk; (1) memberi arahan tentang kegiatan yang akan dilakukan, (2) manajemen kelas, (3) mengurangi tingkat kecemasan dalam berbahasa, (4) memperkenalkan kosa kata baru, (5) memberikan umpan balik (feedback), (6) menjelaskan makna dan (7) memastikan pemahaman siswa (Anggraeni, 2008).

Anggraeni (2008) melaksanakan penelitian pada sebuah kelas di TK bilingual, SWCC Salatiga. Penelitian tersebut bertujuan untuk mengobservasi penggunaan bahasa pertama pada kelas tersebut. Peneliti akhirnya menemukan bahwa bahasa pertama memiliki peran yang sangat penting dalam pembelajaran Bahasa Inggris untuk AUD karena bahasa pertama meberi kontribusi positif pada pembelajaran dan guru mesih menggunakan bahasa pertama sesuai dengan fungsi-fungsi yang disebutkan diatas.

\section{O. Ajaklah seorang penutur asli Bahasa Inggris ke kelas}

Professor Jack C. Richard menyarankan agar mengundang seorang penutur asli ke kelas anak usia dini jika memungkinkan. Jika penutur asli yang didatangkan adalah seorang pengajar, beliau bisa megajak siswa untuk berinteraksi dalam melakukan kegiatan yang sederhana. Namun jika penutur asli yang didatangkan adalah anak-anak, buat mereka bekerja dalam 1 kelompok untuk saling berinteraksi atau bekerjasama dalam kegiatan bermain peran.

Sebuah penelitian yang dikasanakan oleh Sahin (2005) menunjukkan bahwa siswa yang diajarkan oleh penutur asli bahasa Inggris menunjukkan sikap yang lebih positif dan hasil belajar yang lebih baik dibandingkan dengan kelompok siswa yang tidak diajar oleh 
penutur asli bahasa Inggris. Peneliti juga menyimpulkan bahwa, semakin baik sikap yang ditunjukkan oleh siswa terhadap Bahasa Inggris, semakin baik pula hasil belajar yang didapatkan.

\section{KESIMPULAN}

Seluruh pendekatan pembelajaran bahasa Inggris untuk anak usia dini yang telah disampaikan oleh Profesor Jack. C. Richard pada halaman web resminya merupakan 15 pendekatan yang mudah untuk dipahami dan diimplementasikan, dimana praktisi PAUD dalam hal ini para pengajar paud diharapkan untuk; (1) melaksanakan pembelajaran yang penuh dengan aktivitas siswa dan gerakan fisik, (2) memilih aktivitas-aktivitas yang berkaitan dalam suatu kesatuan pembelajaran, (3) memberikan tugastugas atau kegiatan yang bermakna dan penting untuk perkembangan anak pada kehidupan sehari-hari, (4) mendukung proses pembelajaran anak dengan menyediakan bantuan baik dari guru, teman dan orang tua sebagai scaffolding, (5) melibatkan siswa dalam proses pemilihan sumber belajar, (6) melaksanakan pembelajaran dengan tema tertentu, (7) memilihlah topik dan materi pembelajaran yang mudah dikenali siswa, (8) selalu mengutamakan kegiatan pembelajaran yang memberikan kesempatan kepada siswa untuk bekerja berkelompok, (9) selalu menciptakan suasana belajar yang saling mendukung antar siswa di kelas, (10) memilih aktivitas yang menarik dan menyenangkan dan dapat dikerjakan tanpa membuat siswa merasa frustasi, (11) menyediakan sarana dan pra-sarana pendukung pembelajaran bahasa Inggris yang dapat mempermudah baik guru maupun siswa dalam pembelajaran Bahasa Inggris, (12) menyampaikan tujuan pembelajaran dan berikan umpan balik (feedback) dengan jelas untuk meningkatkan hasil belajar siswa, (13) selalu menggunakan bahasa Inggris dalam memberi instruksi majemen kelas, (14) pada saat tertentu, (mother tongue/L1) bahasa ibu atau bahasa pertama anak-anak dapat digunakan untuk memperkenalkan kosakata baru dan menjelaskan langkah kegiatan, dan (15) dengan mengajak seorang penutur asli Bahasa Inggris ke kelas, siswa akan merasa tertarik dan lebih termotivasi.

Seluruh pendekatan yang disebut diatas telah diuji effektifitasnya melalui penelitian-penelitian yang dilakukan oleh para ahli. Sebagian besar experimen yang dilaksanakan diatas merupakan bukti empiris tyang membuktikan bahwa pendekatandanmetodepembelajaranyang dipaparkan oeh Professor Jack C. Richard terbukti effektif dalam meningkatkan kualitas pembelajaran, sehingga tujuan pendidikan Bahasa Inggris untuk anak usia dini dapat tercapai. Oleh karena itu, penulis dapat menyarankan kepada para praktisi pendidikan anak usia dini untuk mempelajari dan mengimplementasikan pendekatan-pendekatan yang ditawarkan diatas agar pelaksanaan proses belajar mengajar bahasa Inggris di PAUD semakin baik dan berkualitas sehingga tidak lagi timbul keragu-raguan tentang kesesuaian metode pembelajaran dengan kondisi tumbuh kembang anak usia dini. Disamping itu, kepada para peneliti yang 
tertarik untuk mengembangkan keilmuan pembelajaran bahasa Inggris untuk anak usia dini, disarankan untuk melaksanakan berbagai penelitian terkait dengan metode pembelajaran bahasa Inggris yang cocok diterapkan ntuk anak usia dini, terutama metode yang dapat mengakomodasi kearifan lokal dalam pembelajaran Bahasa Inggis.

\section{DAFTAR PUSTAKA}

Anggraeni, C.W. 2008. The Purpose of L1 in Teaching English to Young Learners in Kindergarten. Online Article of Universitas Kristen Satya Wacana. From http://eprints.umk. ac.id/7007/10/The-2nd-TEYLINilovepdf-compressed-84-89.pdf

Fawcett, L.M., \& Garton, A.F. 2005. The Effect of Peer Collaboration on Children's Problem-Solving Ability. British Journal of Educational Psychology (2005), 75, 157-169. DOI:10.1348/000709904X23411

Henderlong, J. \& Lepper, M.R. 2002. The Effects of Praise on Children's Intrinsic Motivation: A Review and Synthesis. Psychological Bulletin Copyright, 128, 5, 774-795. DOI 10.1037//0033-2909.128.5.774

Pentimonti, J.M. 2011. Meeting the Needs of All Children: The Use and Impact of Scaffolding in the Preschool Classroom. Unpblished Doctoral Dissertation. The Ohio State University. Online. https://etd. ohiolink.edu/rws_etd/document/ get/osu1306336860/ inline
Richard, J.C. 2018. Methods and Techniques for Young Learners. Online. (https://www. professorjackrichards.com/ methods-and-techniques-foryoung-learners/) diakses pada 25 Februari 2018.

Rokhayani, A. 2017. Promoting Total Physical Response (Tpr) for Young Learners in English Class. The 2nd TEYLIN International Conference Proceedings, p.75-80. http://eprints.umk.ac.id/7007/10/ The-2nd-TEYLIN-ilovepdfcompressed-84-89.pdf

Sahin, I. 2005. The Effect of Native Speaker Teachers of English on the Attitudes and Achievement of Learners. Journal of Language and Linguistic Studies. (1), 1, 50-42. http://www.jlls.org/index.php/j1ls/ article/view/4/5

Salinan Peraturan Menteri Pendidikan dan Kebudayaan Republik Indonesia Nomor 137 Tahun 2014 Tentang Standar nasional pendidikan Anak Usia Dini. Online, (https://luk.staff.ugm. ac.id/atur/bsnp/Permendikbud1372014StandarNasionalPAUD. pdf), diakses 10 Januari 2016

Stojkovic, N. \& Zivkovic, S. 2013. Teaching Cultural Content as a Means of Enriching the Future Identity of Young Language Learners. Integrating Culture and Language Teaching in TEYL Conference Proceeding No. 16. http://www.pefja.kg.ac. rs/ preuzimanje/TEYL\%202015/ TEYL_Conference_2012.pdf 